\title{
COVID-19 and air pollution: the worst is yet to come
}

\author{
Frédéric Dutheil ${ }^{1}$ (D) Julien S. Baker ${ }^{2} \cdot$ Valentin Navel $^{3}$ (D) \\ Received: 15 June 2020 / Accepted: 30 September 2020 / Published online: 6 October 2020 \\ (C) Springer-Verlag GmbH Germany, part of Springer Nature 2020
}

To the Editor:

We read with interest the article by Wang et al. highlighting the burden of transport industry to carbon emissions in China (Wang et al. 2020). The authors described a massive increase of carbon emissions from fossil fuel in China, with an average annual growth rate of $9.72 \%$. Interestingly, Northeastern China (epicenter of the beginning of COVID-19 pandemic) is particularly affected by this massive increase of carbon emissions related to transportation, with a northeastsouthwest pattern. However, satellite images showed a massive decrease in nitrogen dioxide $\left(\mathrm{NO}_{2}\right)$, carbon dioxide $\left(\mathrm{CO}_{2}\right)$, and ozone $\left(\mathrm{O}_{3}\right)$, which was related to the reduction of human activities during the SARS-CoV-2 outbreak, i.e., traffic road, industrial productions, and individual traffic commuting (Dutheil et al. 2020). In the dramatical context of the SARS-CoV-2 pandemic, this global reduction in air pollution was a great sign for the preservation of our environment and some of the related cardiovascular and respiratory tract diseases (Guan et al. 2016; Cramer et al. 2020). More than half of humanity stayed at home for several months to avoid SARS-

Comment on: "Spatio-temporal characteristics of the relationship between carbon emissions and economic growth in China's transportation industry."

Responsible editor: Philippe Garrigues

Frédéric Dutheil

fdutheil@chu-clermontferrand.fr

1 CHU Clermont-Ferrand, University Hospital of Clermont-Ferrand, Preventive and Occupational Medicine, CNRS, LaPSCo, Physiological and Psychosocial Stress, Witty Fit, Université Clermont Auvergne, 58 rue Montalembert,

F-63000 Clermont-Ferrand, France

2 Department of Sport, Physical Education and Health, Centre for Health and Exercise Science Research, Hong Kong Baptist University, Kowloon Tong, Hong Kong

3 Université Clermont Auvergne, CNRS, INSERM, GReD, Translational Approach to Epithelial Injury and Repair, CHU Clermont-Ferrand, Ophthalmology, University Hospital of Clermont-Ferrand, F-63000 Clermont-Ferrand, France
CoV-2 spreading. The isolation period has been referred to as a global economic crisis similar to the peak unemployment problems of the Great Depression (Arengo and Fuller 2020). However, to reduce the extent of the financial market collapse, some countries promptly reviewed the strict social distancing policy to boost industrial production and economic recovery (McCaffrey 2020). Some countries have already publicly stated that they will not meet the Paris agreement on climate change initiatives in order to boost their economic growth. China seems to increase the carbon-intensive development path, in accordance with the USA that wants to rescue struggling fossil fuel production firms (Harrabin 2020). Moreover, most of the worldwide trade routes were disrupted to fight against the COVID-19 pandemic, limiting economic exchanges and access to energy resources. This critical situation increases the exploitation of pollutant fossil fuels, particularly the redevelopment of previously closed carbon mines (Lelieveld et al. 2019). In addition to the probable increase in air pollution to fight against the 2-month lockdown in relation to the economy, individual behavior will also increase air pollution. Fearing the contagion in mass transit, people are more frequently using their individual cars for commuting (Smargiassi et al. 2020) - taking into account that traffic involves around $70 \%$ of air pollutants in urban areas (Ramacher and Karl 2020). There is also a noticeable upsurge in the use of disposable plastic, in line with mass media disseminating the survival of SARS-Cov-2 on inert surfaces (Otter et al. 2016). Considering the millions of tons of plastic waste entering the ocean each year, the global burden of plastic pollution will probably characterize the Anthropocene era as geological marker in the history of humanity (Jambeck et al. 2015). Thus, even if people fear a second wave of COVID-19, there may also be a tsunami of global pollution. Countries that are most affected by the SARS-CoV-2 pandemic may also be those with the highest economic consequences of the lockdown, and these countries may also have the highest increases in air pollution. Even if the global lockdown period benefitted air quality, we fear that countries worldwide will choose to protect the economy rather than the environment. This strategy might paradoxically cost more money than the massive 
containment due to SARS-CoV-2 restrictions - not meeting the Paris agreement may cost more than 600 trillion USD over the twenty-first century (Wei et al. 2020). The SARS-CoV-2 outbreak seems likely to be a brief respite in the fate of the world's increased air pollution.

\section{Compliance with ethical standards}

Conflict of interest The authors declare that they have no conflict of interest.

\section{References}

Arengo T, Fuller T (2020) The Price of a virus lockdown: economic 'free fall' in California. The New York Times

Cramer J, Jørgensen JT, Hoffmann B, Loft S, Bräuner EV, Prescott E, Ketzel M, Hertel O, Brandt J, Jensen SS, Backalarz C, Simonsen MK, Andersen ZJ (2020) Long-term exposure to air pollution and incidence of myocardial infarction: a Danish nurse cohort study. Environ Health Perspect 128:57003. https://doi.org/10.1289/ EHP5818

Dutheil F, Baker JS, Navel V (2020) COVID-19 as a factor influencing air pollution? Environ Pollut 263:114466. https://doi.org/10.1016/j. envpol.2020.114466

Guan W-J, Zheng X-Y, Chung KF, Zhong N-S (2016) Impact of air pollution on the burden of chronic respiratory diseases in China: time for urgent action. Lancet 388:1939-1951. https://doi.org/10. 1016/S0140-6736(16)31597-5

Harrabin R (2020) Coronavirus recovery plan "must tackle climate change." BBC News

Jambeck JR, Geyer R, Wilcox C, Siegler TR, Perryman M, Andrady A, Narayan R, Law KL (2015) Plastic waste inputs from land into the ocean. Science 347:768-771. https://doi.org/10.1126/science. 1260352

Lelieveld J, Klingmüller K, Pozzer A, Burnett RT, Haines A, Ramanathan V (2019) Effects of fossil fuel and total anthropogenic emission removal on public health and climate. Proc Natl Acad Sci U S A 116:7192-7197. https://doi.org/10.1073/pnas.1819989116

McCaffrey D (2020) Coronavirus economic recovery: "now is the time to compromise." Euronews

Otter JA, Donskey C, Yezli S, Douthwaite S, Goldenberg SD, Weber DJ (2016) Transmission of SARS and MERS coronaviruses and influenza virus in healthcare settings: the possible role of dry surface contamination. J Hosp Infect 92:235-250. https://doi.org/10.1016/ j.jhin.2015.08.027

Ramacher MOP, Karl M (2020) Integrating modes of transport in a dynamic modelling approach to evaluate population exposure to ambient NO2 and PM2.5 pollution in urban areas. IJERPH 17:2099. https://doi.org/10.3390/ijerph17062099

Smargiassi A, Plante C, Morency P, Hatzopoulou M, Morency C, Eluru N, Tétreault LF, Goudreau S, Bourbonnais PL, Bhowmik T, Shekarrizfard M, Chandra Iraganaboina N, Requia W (2020) Environmental and health impacts of transportation and land use scenarios in 2061. Environ Res 187:109622. https://doi.org/10. 1016/j.envres.2020.109622

Wang L, Fan J, Wang J, Zhao Y, Li Z, Guo R (2020) Spatio-temporal characteristics of the relationship between carbon emissions and economic growth in China's transportation industry. Environ Sci Pollut Res Int 27:32962-32979. https://doi.org/10.1007/s11356020-08841-x
Wei Y-M, Han R, Wang C, Yu B, Liang QM, Yuan XC, Chang J, Zhao Q, Liao H, Tang B, Yan J, Cheng L, Yang Z (2020) Selfpreservation strategy for approaching global warming targets in the post-Paris agreement era. Nat Commun 11:1624. https://doi. org/10.1038/s41467-020-15453-Z

Publisher's note Springer Nature remains neutral with regard to jurisdictional claims in published maps and institutional affiliations.

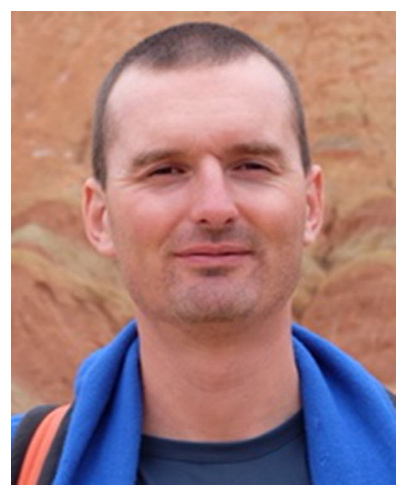

Frédéric Dutheil is a professor in medicine and researcher at the University Hospital of ClermontFerrand (CHU) and Université Clermont Auvergne (UCA). He is currently the head of the Occupational and Environmental Department of the CHU and UCA, since 2017. Member of the "Laboratory of Metabolic Adaptations to Exercise in Clinical and Pathological conditions" (AME2P-EA 3533) from 2006 to 2016, and clinical fellow of the Australian Catholic University (ACU) from 2012 to 2018, his work on biomarkers of stress led him to the creation and the head of the "Physiological and Psychosocial Stress" team at the UMR CNRS 6024 LaPSCo, from 2016. He is also the scientist of Wittyfit, a sofware designed to improve health of workers, through a personalized and individualized feedback of their health, taking into account job characteristics.

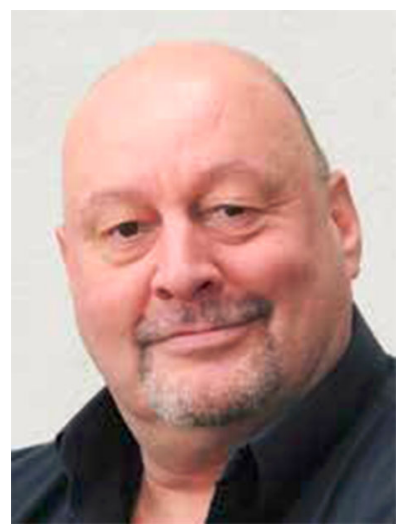

Julien S. Baker has been the Head of Department of Sport and Physical Education, Hong Kong Baptist University, since September 2019. He is a Fellow of the Physiological Society, a member of the American Physiological Society, and the Society for the Study of Biology (SSOB). In addition, he has membership of the British Pharmacological Society, and the Federation of American Societies for Experimental Biology (FASEB). Professor Baker is also an Honorary Professor at the University of Ningbo, and has Visiting Professor status at the University of Sydney and Ningbo University Ninth Hospital Medical Research Centre. 


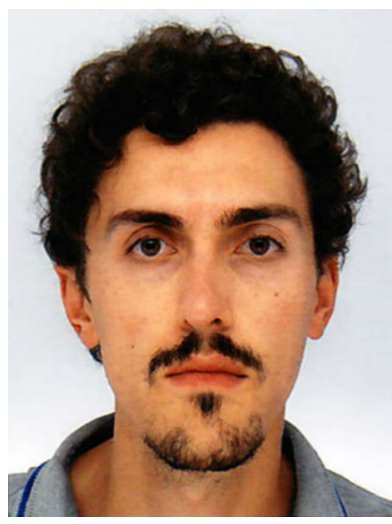

Valentin Navel is a Medical Doctor at the University Hospital of Clermont-Ferrand (CHU) and a researcher at the Université Clermont Auvergne (UCA). He is currently finishing a surgical residency in the ophthalmological department of the CHU ClermontFerrand. He also holds a Master degree from the Institute of Physics and Engineering of Clermont-Ferrand, and continue a $\mathrm{PhD}$ in paternship with the Genetic, Reproduction and Development (GReD) Laboratory. 